\title{
Analisa Probabilitas Perpindahan Moda Transportasi Dari Bus Ke Kereta Api Rute Medan-Kotapinang Menggunakan Metode Stated Preference
}

\author{
Beni ARTANTO ${ }^{1} \cdot$ Medis Sejahtera SURBAKTI ${ }^{2}$
}

\begin{abstract}
The construction of railway line between Rantau Prapat and Kotapinang is expected to ease transportation process from Medan to Kotapinang, which could improve economic activities and become the alternative solution to make a trip. At the moment, existing public transport that covers this route is strictly limited to only medium or big buses. This research aims to identify the characteristic of trip maker and also to analyze the probability of mode shifting from bus to train for the mentioned trip. We use stated preference survey questionnaire, and it was distributed to random minimul sample needed. In order to obtain the utility function of the trip maker, the obtained data was then modeled in binomial logit method using SPSS statistical software. Tthe analyzed attributes difference $(\Delta)$ are trip cost difference $\left(\Delta X_{1}\right)$, waiting time difference $\left(\Delta X_{2}\right)$, travel time difference $\left(\Delta X_{3}\right)$. The generated model has 0.114 of $R^{2}$, and the probability of shifting from bus to train is $31.93 \%$ if the trip cost difference was Rp. 30.000. Meanwhile, the probability of shifting is $50.15 \%$ if the waiting time difference was less then 30 minutes. Lastly, the probability of shifting is $57.96 \%$ if the travel time difference was 1 hour.
\end{abstract}

Kata kunci: pemilihan moda, stated preference, logit binomial

\section{Pendahuluan}

Medan merupakan ibu kota Provinsi Sumatera Utara, yang mana hampir seluruh kegiatan bisnis, industri, dan terutama pusat-pusat pendidikan perguruan tinggi berada di kota Medan. Sehingga tidak heran jika banyak kegiatan transportasi yang terjadi dari daerah lain menuju kota tersebut. Sebagai salah satu contohnya adalah pergerakan pelaku perjalanan dari wilayah Kotapinang menuju Kota Medan dan sebaliknya. Baik untuk kegiatan pendidikan, bisnis, ekonomi atau keperluan lainnya.

Kecelakaan transportasi merupakan salah satu ancaman keselamatan transportasi dalam perjalanan darat dari Medan menuju Kotapinang. Selain karena kesalahan pengemudi, rambu-rambu lalu lintas yang kurang bekerja secara optimal, pengaruh cuaca juga bisa menjadi faktor penyebab terjadinya kecelakaan. Berdasarkan data yang diperoleh dari BPS Pemprov Sumatera Utara diketahui bahwa jumlah kejadian kecelakaan sampai akhir tahun 2016 adalah sebanyak 3.441 kasus.

Dengan berbagai alasan untuk meningkatkan perekonomian dan pemerataan pembangunan infrastruktur serta memberikan layanan moda transportasi yang lebih nyaman dan aman, Pemerintah berwacana untuk melalukan pembangunan jalur kereta api Trans Sumatera. Sebagai salah satu contohnya adalah pembangunan jalur baru rel kereta api Rantau Parapat-

\footnotetext{
${ }^{1}$ Program Studi Teknik Sipil Universitas Sumatera Utara e-mail: benartanto@gmail.com

${ }^{2}$ Staf Pengajar Teknik Sipil Universitas Sumatera Utara
} 
Kotapinang yang telah ditetapkan dengan surat keputusan tim persiapan pengadaan tanah Sekretariat Daerah Pemprov Sumut sejak 23 November 2015.

Adanya pembangunan jalur baru rel kereta api tersebut akan menjadi alternatif baru dalam pemilihan moda untuk melakukan perjalanan dari Medan menuju Kotapinang dan sebaliknya. Karena saat ini transportasi massal eksisting pada rute tersebut hanya berupa moda bus berukuran sedang maupun besar. Dengan demikian, maka penelitian ini dimaksudkan untuk melihat seberapa besar pengaruh pembangunan jalan rel kereta api rute tersebut terhadap peralihan pemilihan moda transportasi dari bus ke kereta api yang dilakukan oleh pelaku perjalanan. Kajian ini dilakukan dengan menggunakan pendekatan Stated Preference dan Discrete Choice Models. Selain itu apakah atribut yang paling berpengaruh dalam pemilihan moda transportasi untuk rute perjalanan tersebut. Sehingga dengan studi ini diharapkan dapat dihasilkan rekomendasi langkah perbaikan yang dapat dilakukan oleh instansi terkait.

\section{Tinjauan Pustaka}

\section{Model Pemilihan Moda Transportasi}

Pemilihan moda dapat didefenisikan sebagai pembagian dari perjalanan yang dilakukan oleh pelaku perjalanan ke dalam moda yang tersedia dengan berbagai faktor yang mempengaruhi. Tahap pemilihan moda ini merupakan suatu tahapan proses perencanaan angkutan yang berfungsi untuk menentukan pembebanan perjalanan atau mengetahui jumlah (dalam arti proporsi) orang dan barang yang akan menggunakan atau memilih berbagai moda transportasi untuk melayani suatu titik asal-tujuan tertentu.

\section{Model Pemilihan Diskret}

Pemilihan diskret dinyatakan sebagai peluang setiap individu untuk memilih suatu pilihan merupakan fungsi ciri sosio-ekonomi dan daya tarik pilihan tersebut. Konsumen memaksimalkan kepuasannya dalam mengkonsumsi pelayanan yang diberikan oleh suatu moda transportasi. Si konsumen menjadi seorang pengambil keputusan dan akan menyeleksi berbagai alternatif dan memutuskan memilih moda yang memiliki nilai kepuasan tertinggi (highest utility).

\section{Model Logit Biner/Binomial}

Pada model logit binomial ini, konsumen dihadapkan pada dua pilihan moda, dimana moda yang akan dipilih berupa moda yang mempunyai nilai utilitas yang paling tinggi dan utilitas dianggap sebagai variabel acak dengan residu Gumbel yang tersebar bebas dan identik.

Persamaan model logit binomial dapat dituliskan sebagai berikut:

$$
\frac{P_{i}}{P_{i}}-\exp \left(U_{i}-U_{i}\right)
$$

$\mathrm{Pj} \quad=$ probabilitas $(\%)$ peluang moda $\mathrm{j}$ untuk dipilih

$\mathrm{Pi} \quad=$ probabilitas $(\%)$ peluang moda $\mathrm{i}$ untuk dipilih

Exp = eksponensial

$\mathrm{Uj} \quad=$ nilai kepuasan konsumen (utilitas) menggunakan moda $\mathrm{j}$

$\mathrm{Ui}=$ nilai kepuasan konsumen (utilitas) menggunakan moda $\mathrm{i}$

\section{Teknik Stated Preference}

Teknik Stated preference merupakan teknik pengumpulan data yang mengacu pada pendekatan terhadap pendapat responden dalam menghadapi berbagai pilihan alternatif. 
Teknik ini menggunakan desain eksperimental untuk membuat sejumlah alternatif situasi imajiner. Langkah yang dilakukan untuk mengidentifikasi bagaimana responden merespon jika situasi imajiner tersebut benar-benar ada dalam realita adalah dengan menanyakan langsung pada responden tersebut. Kemudian peneliti dapat melakukan kontrol terhadap semua faktor yang dibuat dalam alternatif pilihan yang ditawarkan. Pendapat responden tersebut bisa dinyatakan dalam bentuk rangking, rating, maupun pilihan.

\section{Metode Penelitian}

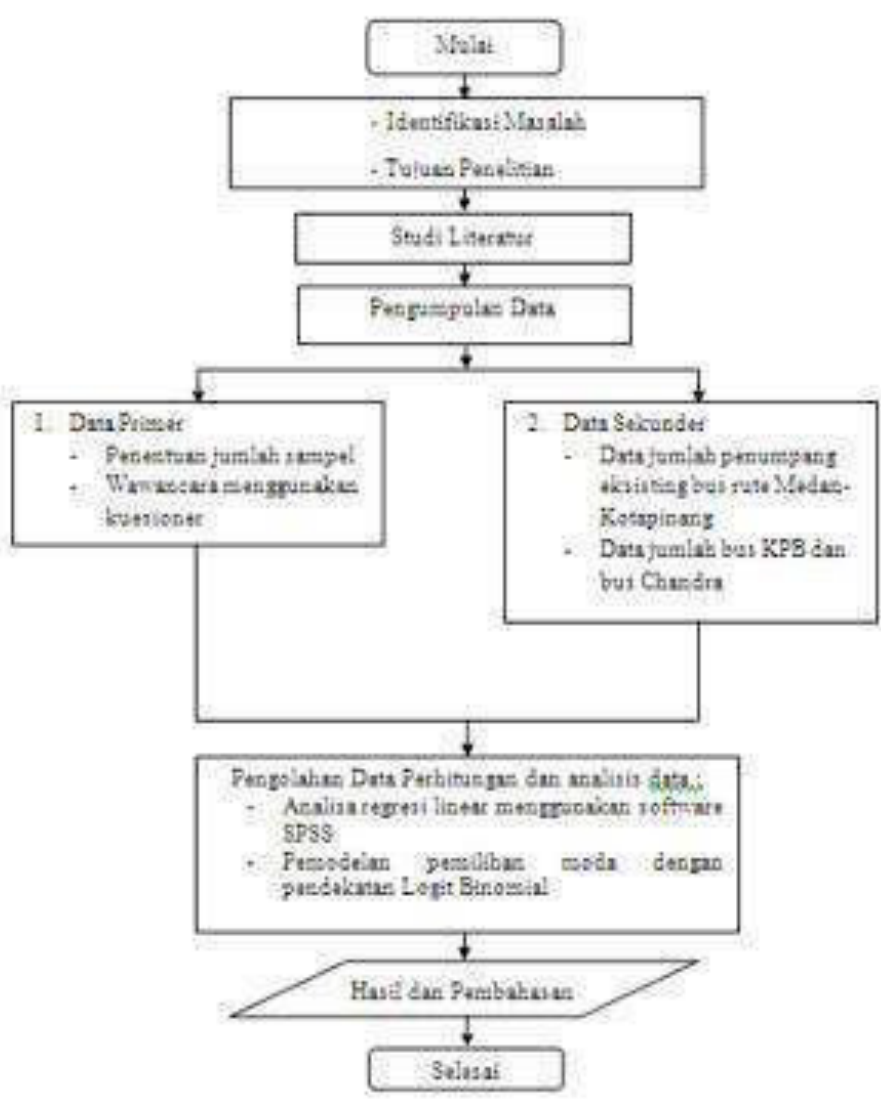

Gambar 1. Diagram Alir Penelitian

\section{Penentuan Jumlah Sampel}

Menurut Yamane (1967) dikutip oleh Glen D. Israel (2012) dalam jurnalnya "Determining Sample Size”, dinyatakan bahwa untuk menghitung jumlah sampel yang akan digunakan dalam penelitian dapat dihitung dengan menggunakan persamaan berikut:

$$
n=\frac{N}{1+N(c)^{2}}
$$

Dengan jumlah penumpang eksisting sebanyak 412 orang dan tingkat ketelitian $0,1 \%$ maka:

$$
\begin{gathered}
n=\frac{412}{1+412(0 ; 1)^{2}} \\
\mathrm{u}=80,46075 \approx 81 \text { responden }
\end{gathered}
$$

Jadi jumlah responden digenapkan menjadi 100 orang. 


\section{Penyusunan Kuesioner}

Dalam penyusunan kuesioner, pertanyaan-pertanyaan yang diajukan berupa karakteristik pelaku perjalanan, karakteristik perjalanan dan respon terhadap perubhan atribut-atribut yang berpengaruh terhadap pemilihan moda.

Kemudian biaya perjalanan, waktu tempuh dan juga waktu keberangkatan. Jawaban yang diberikan responden akan ditransformasikan kedalam skala numerik 1-5 yang dapat dilihat pada tabel berikut.

Tabel 1. Skala Pilihan dan Pernyataan

\begin{tabular}{|c|l|c|}
\hline Skala & \multicolumn{1}{|c|}{ Pernyataan } & Skala Probabilitas (P) \\
\hline 1 & Pasti memilih kereta api & 0,9 \\
\hline 2 & Mungkin memilih kereta api & 0,7 \\
\hline 3 & pilihan berimbang & 0,5 \\
\hline 4 & mungkin memilih bus & 0,3 \\
\hline 5 & pasti memilih bus & 0,1 \\
\hline
\end{tabular}

\section{Pengolahan Data}

Adapun data-data yang diperoleh dari kuesioner yang telah diberikan kepada responden selanjutnya akan disajikan pada format Microsoft Excel dalam skala numerik sebagai variabel tidak bebas dan selisih nilai atribut moda bus dan kereta api sebagai variabel bebas. Pengolahan data penelitian ini terdapat dua proses analisis yang dilakukan, yaitu:

a. Analisis Karakteristik Pelaku perjalanan dan Karakteristik Perjalanan

Untuk menganalisis data karakteristik pelaku perjalanan dan karakteristik perjalanan digunakan analisis statistik deskriptif. Kemudian data-data tersebut akan ditampilkan menjadi sebuah diagram untuk melihat persentase dari masing-masing pilihan yang telah diberikan oleh responden.

b. Analisa Pemilihan Moda

Analisa ini berfungsi untuk memodelkan probabilitas pengguna moda bus berpindah ke kereta api dengan dengan mempertimbangkan atribut biaya perjalanan, waktu perjalanan dan waktu tunggu.

c. Pemodelan Pemilihan Moda

Metode yang digunakan dalam pemodelan pemilihan moda antara bus dan kereta api adalah model logit biner dengan menggunakan persamaan:

Keterangan:

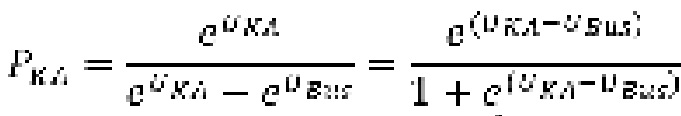

$$
\begin{aligned}
& P_{K A}=1+P_{K A}=\frac{1}{1+e^{\left(L_{K A}-i_{S u s i}\right)}}
\end{aligned}
$$

$\mathrm{P}_{\mathrm{KA}} \quad=$ probabilitas pemilihan moda kereta api

$\mathrm{P}_{\mathrm{Bus}} \quad=$ probabilitas pemilihan moda eksisting (bus)

$\mathrm{U}_{\mathrm{KA}} \quad$ = fungsi utilitas moda kereta api

$\mathrm{U}_{\mathrm{Bus}} \quad=$ fungsi utilitas moda eksisting 


\section{Hasil dan Pembahasan}

\section{Karakteristik Umum Pelaku Perjalanan/Responden}
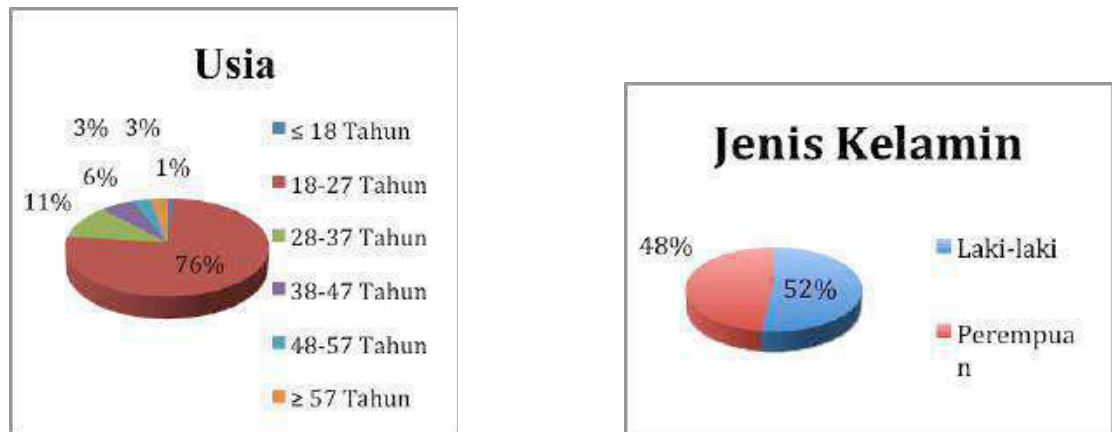

Gambar 1. Karakteristik Usia dan Jenis Kelamin Responden
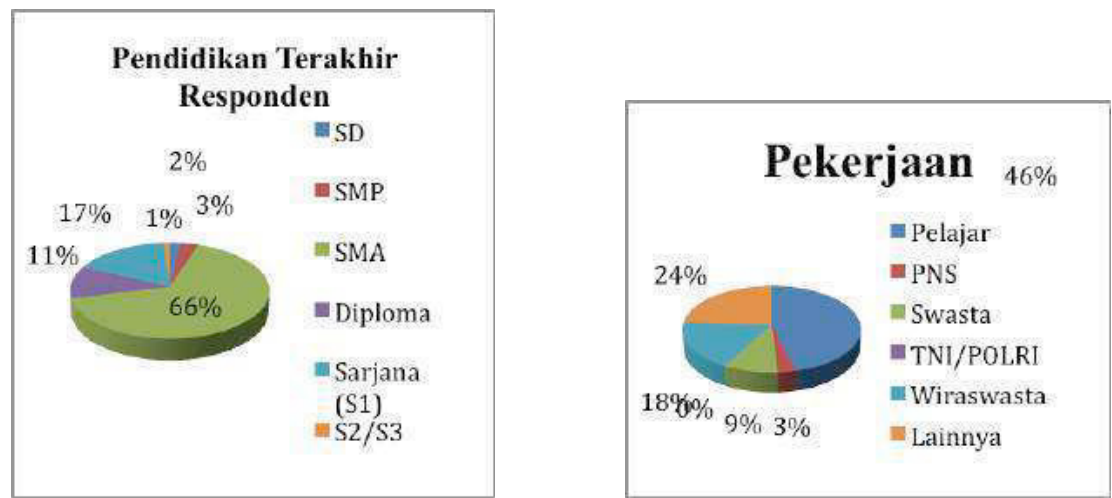

Gambar 2. Karakteristik Pendidikan dan Pekerjaan Responden
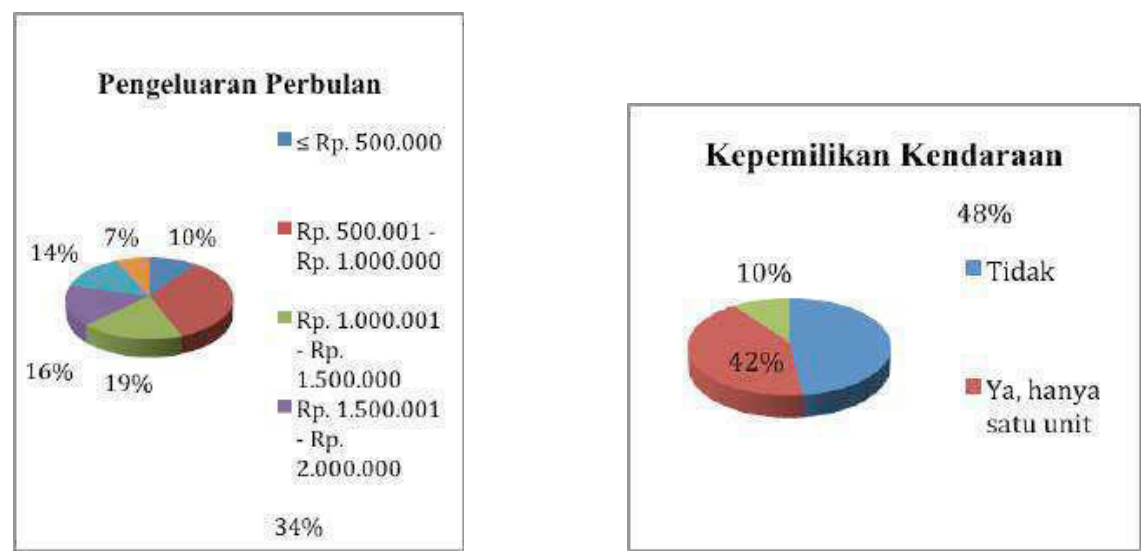

Gambar 3. Karakteristik Pengeluaran dan Kepemilikan Kendaraan Responden 


\section{Karakteristik Perjalanan Responden}
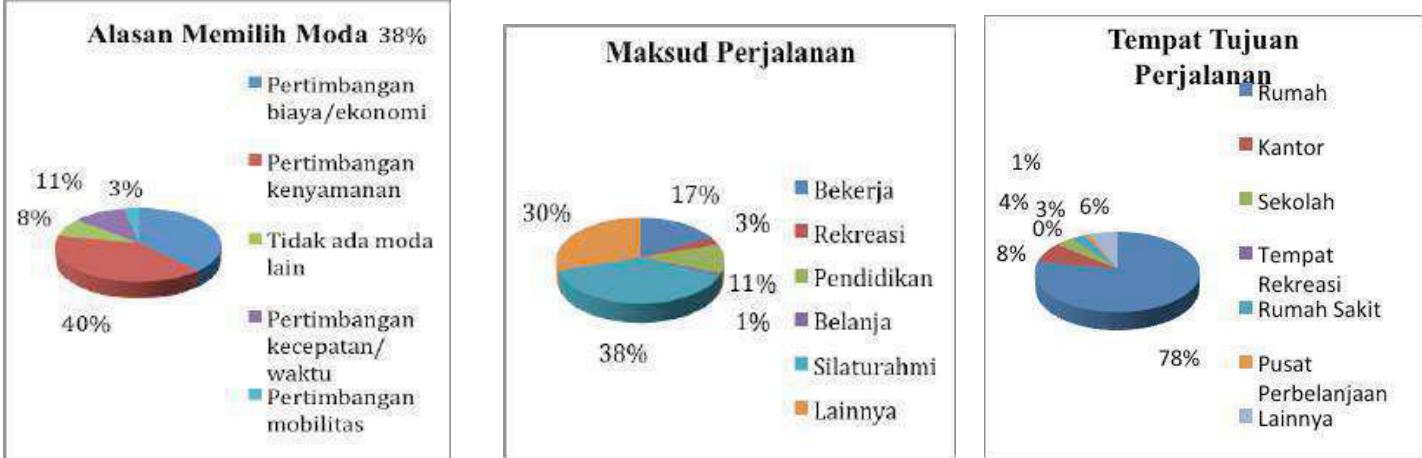

Gambar 4. Karakteristik Alasan Memilih Moda, Maksud dan Tempat Tujuan Perjalanan Responden
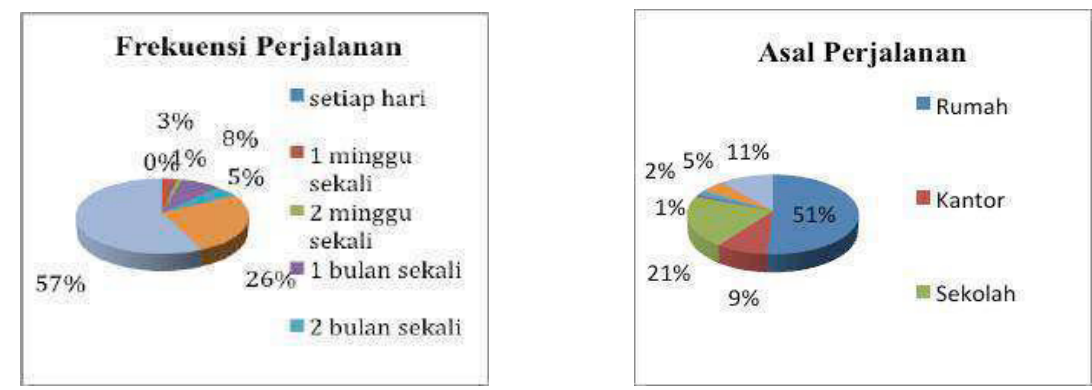

Gambar 5. Karakteristik Frekuensi Perjalanan dan Asal Perjalanan Responden
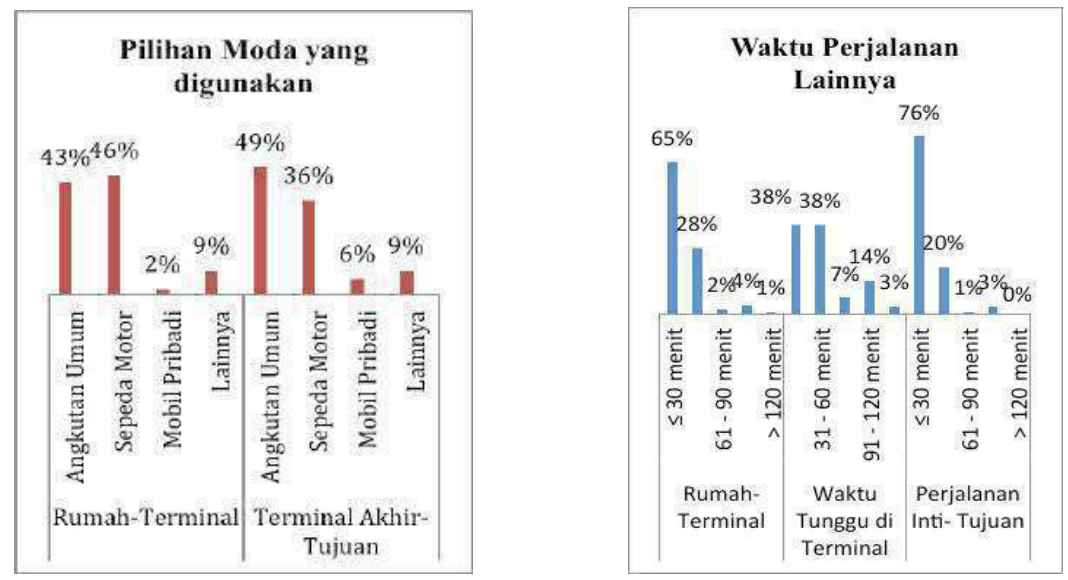

Gambar 6. Karakteristik Pilihan Moda dan Waktu Perjalanan Lainnya Responden
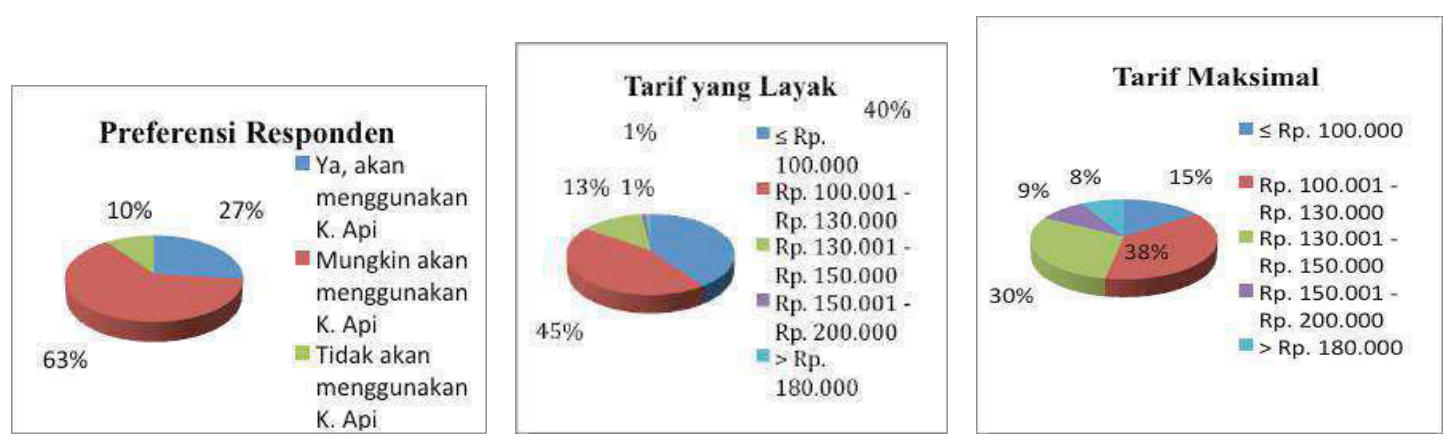

Gambar 7. Karakteristik Preferensi Moda, Tarif Layak, dan Tarif Maksimal Menurut Responden 


\section{Analisa Pemilihan Moda Berdasarkan Data Stated Preference}

Berdasarkan survey pendahuluan yang telah dilakukan guna mendapatkan data sekunder mengenai kondisi eksisting bus berupa biaya, waktu tunggu dan waktu tempuh perjalanan yang dibutuhkan pelaku perjalanan, diperoleh kondisi atribut yang akan dibandingkan dengan atribut serupa pada moda kereta api. Kondisi eksisting tersebut disajikan pada tabel berikut.

Tabel 2. Asumsi Kondisi Eksisting Atribut yang diteliti

\begin{tabular}{|l|l|l|}
\hline No. & Asumsi Atribut & Moda Angkutan Bus \\
\hline 1 & Biaya Perjalanan & Rp. $90.000,-$ \\
\hline 2 & Waktu Tempuh & 9 jam \\
\hline 3 & Waktu Tunggu Keberangkatan & 30 menit \\
\hline
\end{tabular}

\section{Analisa Persamaan Fungsi Selisih Utilitas}

Tabel 3. Hasil Respon Terhadap Selisih Biaya Perjalanan (ribuan Rupiah) Antara Bus dan Kereta Api

\begin{tabular}{|c|c|c|c|c|c|c|}
\hline \multirow{2}{*}{ Pilihan } & \multirow{2}{*}{$\begin{array}{c}\Delta \mathbf{X 1} \\
\text { (Ribuan) }\end{array}$} & \multicolumn{6}{|c|}{ Jumlah Responden Masing-masing Rating } \\
\cline { 3 - 7 } & $\mathbf{1}$ & $\mathbf{2}$ & $\mathbf{3}$ & $\mathbf{4}$ & $\mathbf{5}$ \\
\hline $\mathbf{1}$ & 40 & 26 & 27 & 0 & 29 & 18 \\
\hline $\mathbf{2}$ & 45 & 18 & 19 & 2 & 38 & 23 \\
\hline $\mathbf{3}$ & 50 & 11 & 14 & 2 & 35 & 41 \\
\hline $\mathbf{4}$ & 55 & 5 & 9 & 2 & 35 & 49 \\
\hline $\mathbf{5}$ & 60 & 4 & 6 & 2 & 35 & 53 \\
\hline
\end{tabular}

Tabel 4. Hasil Respon Terhadap Selisih Waktu Tunggu Antara Bus dan Kereta Api

\begin{tabular}{|c|c|c|c|c|c|c|}
\hline \multirow{2}{*}{ Pilihan } & \multirow{\Delta}{*}{$\mathbf{X 2}$} \\
& Menit) & \multicolumn{6}{|c|}{ Jumlah Responden Masing-masing Rating } \\
\cline { 3 - 7 } & 120 & 18 & 13 & 0 & 30 & 39 \\
\hline $\mathbf{1}$ & 150 & 12 & 12 & 1 & 36 & 39 \\
\hline $\mathbf{2}$ & 150 & 5 & 8 & 1 & 35 & 51 \\
\hline $\mathbf{3}$ & 180 & 6 & 6 & 1 & 29 & 58 \\
\hline $\mathbf{4}$ & 210 & $\mathbf{2}$ & 7 & 2 & 27 & 59 \\
\hline $\mathbf{5}$ & 240 & 5 & & & & \\
\hline
\end{tabular}

Tabel 5. Hasil Respon Terhadap Selisih Waktu Tempuh (Jam) Antara Bus dan Kereta Api

\begin{tabular}{|c|c|c|c|c|c|c|}
\hline \multirow{2}{*}{ Pilihan } & \multirow{2}{*}{$\begin{array}{c}\mathbf{X} 3 \\
(\mathbf{J a m})\end{array}$} & \multicolumn{6}{|c|}{ Jumlah Responden Masing-masing Rating } \\
\cline { 3 - 7 } & $\mathbf{1}$ & $\mathbf{2}$ & $\mathbf{3}$ & $\mathbf{4}$ & $\mathbf{5}$ \\
\hline $\mathbf{1}$ & $-2,5$ & 49 & 31 & 1 & 8 & 11 \\
\hline $\mathbf{2}$ & $-2,25$ & 48 & 27 & 1 & 12 & 12 \\
\hline $\mathbf{3}$ & -2 & 41 & 26 & 1 & 16 & 16 \\
\hline $\mathbf{4}$ & $-1,75$ & 32 & 20 & 1 & 25 & 22 \\
\hline $\mathbf{5}$ & $-1,5$ & 30 & 19 & 1 & 23 & 27 \\
\hline
\end{tabular}

\section{Model Pemilihan Moda}

Uji korelasi berfungsi untuk mengetahui seberapa besar hubungan antara variabel-variabel bebas terhadap variabel tidak bebas. Nilai korelasi yang tinggi menunjukkan bahwa terdapat korelasi yang erat antara variabel yang tergantung pada variabel yang lain, sedangkan nilai 
yang rendah menunjukkan korelasi yang tidak erat antara variabel yang tergantung pada yang lain dengan variabel bebas.

Tabel 6. Kriteria Hubungan Korelasi Antar Variabel

\begin{tabular}{|c|c|}
\hline Nilai r & Kriteria Hubungan \\
\hline 0 & Tidak ada korelasi \\
\hline $0-0,5$ & Korelasi lemah \\
\hline $0,5-0,8$ & Korelasi sedang \\
\hline $0,8-1$ & Korelasi kuat \\
\hline 1 & Korelasi sempurna \\
\hline
\end{tabular}

Alternatif Persamaan Fungsi Selisih Utilitas antara Kereta Api dengan Bus

Alternatif persamaan yang dibentuk adalah:

1. Alternatif 1 dengan $\mathrm{R}^{2}=0,043$

$$
y=a+b_{i} x_{1}
$$

2. Alternatif 2 dengan $\mathrm{R}^{2}=0,016$

$$
y=a+b_{2} x_{2}
$$

3. Alternatif 3 dengan $\mathrm{R}^{2}=0,075$

$$
y=a+b_{3} x_{3}
$$

4. Alternatif 4 dengan $\mathrm{R}^{2}=0,108$

$$
y=a+b_{2} x_{1}+b_{2} x_{2}
$$

5. Alternatif 5 dengan $\mathrm{R}^{2}=0,082$

$$
y=a+b_{1} x_{1}+b_{3} x_{3}
$$

6. Alternatif 6 dengan $\mathrm{R}^{2}=0,075$

$$
y=a+b_{2} x_{2}+b_{3} x_{1}
$$

7. Alternatif 7 dengan $\mathrm{R}^{2}=0,114$

$$
y=a+b_{1} x_{1}+b_{2} x_{2}+b_{3} x_{3}
$$

Dari beberapa alternatif persamaan di atas dipilih persamaan dengan nilai $\mathrm{R}^{2}$ terbesar yaitu persamaan altgernatif 7 sebesar $0,114(11,4 \%)$.

\section{Persamaan Model Kereta Api dengan Bus}

Persamaan selisih utilitas kereta api dan bus dengan nilai $\mathrm{R}^{2}$ tertinggi yang didapat dari hasil pengolahan SPSS adalah:

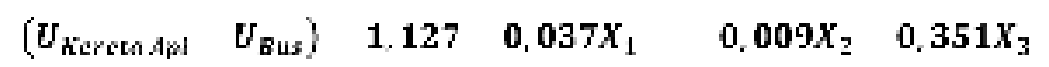

Keterangan:

$\mathrm{X}_{1} \quad=$ Selisih Biaya Perjalanan (Puluhan Ribu Rupiah)

$\mathrm{X}_{2} \quad=$ Selisih Waktu Tunggu (Menit)

$\mathrm{X}_{3}=$ Selisih Waktu Tempuh (Jam)

Sehingga probabilitas pemilihan moda antara kereta api dengan bus adalah sebagai berikut:

$$
\begin{gathered}
P_{K A}=\frac{e^{\left(1,127-0,037 x_{1}-0.009 X_{2}-0.351 X_{3}\right)}}{1+e^{\left(1.127-0.037 X_{1}-0,009 X_{2}-0,351 x_{3}\right)}} \\
P_{\mathrm{LLE}}=1-P_{K A}
\end{gathered}
$$




\section{Validasi Persamaan Model dengan Uji Statistik}

a. Uji Signifikansi (Uji F)

Uji ini dilakukan untuk memastikan seluruh atribut yang terdapat dalam persamaan apakah memiliki pengaruh atau tidak terhadap variabel tidak bebas.

\begin{tabular}{|rl|r|r|r|r|r|}
\hline \multicolumn{2}{|l|}{ Model } & $\begin{array}{r}\text { Sum of } \\
\text { Squares }\end{array}$ & Df & Mean Square & F & Sig. \\
\hline 1 & Regression & 483,452 & 3 & 161,151 & 64,137 &, 000 (a) \\
& Residual & 3758,857 & 1496 & 2,513 & & \\
& Total & 4242,310 & 1499 & & & \\
& & & & & \\
\hline
\end{tabular}

Berdasarkan tabel Anova di atas (Alternatif 7) diketahui bahwa nilai F dari persamaan model ialah 64,137 dengan nilai signifikansi 0,000.

df1 $=\mathrm{k}-1$ maka $3-1=2$

$\mathrm{df} 2=\mathrm{n}-\mathrm{k}$ maka $100-3=97$

Nilai $\mathrm{F}$ tabel dapat diketahui dengan melihat tabel $\mathrm{F}(0,05 ; 2 ; 97)$ didapat 3,09 yang berarti $\mathrm{F}$ hitung $>$ nilai $\mathrm{F}$ maka $\mathrm{H}_{\mathrm{o}}$ ditolak dan $\mathrm{H}_{\mathrm{a}}$ diterima, sedangkan berdasarkan nilai signifikansi didapat $0,000<0,025$ dengan demikian $\mathrm{H}_{\mathrm{o}}$ ditolak dan $\mathrm{H}_{\mathrm{a}}$ diterima. Dengan demikian dapat disimpulkan bahwa atribut biaya, waktu tunggu dan waktu tempuh serentak berpengaruh terahadap pemilihan moda.

b. Uji Parsial (Uji T)

Uji T dilakukan untuk mengetahui pengaruh variabel terikat secara parsial terhadap variabel bebas, apakah memiliki pengaruh yang signifikan atau tidak.

\begin{tabular}{|c|c|c|c|c|c|c|}
\hline \multicolumn{2}{|c|}{ Model } & \multicolumn{2}{|c|}{$\begin{array}{l}\text { Unstandardized } \\
\text { Coefficients }\end{array}$} & \multirow{2}{*}{$\begin{array}{c}\text { Standardized } \\
\text { Coefficients } \\
\text { Beta }\end{array}$} & \multirow{2}{*}{$\begin{array}{c}\mathrm{T} \\
\text { Lower } \\
\text { Bound }\end{array}$} & \multirow{2}{*}{$\begin{array}{c}\text { Sig. } \\
\text { Upper Bouno }\end{array}$} \\
\hline & & B & Std. Error & & & \\
\hline \multirow[t]{4}{*}{1} & (Constant) & 1,127 & 221 & & 5,089 &, 000 \\
\hline & Selisih Biaya &,- 037 &, 005 &,- 527 & $-8,126$ & 000 \\
\hline & Selisih Waktu Tunggu &,- 009 &, 001 &,- 470 & $-7,302$ &, 000 \\
\hline & Selisih Waktu Tempuh &,- 351 & ,113 &,- 201 & $-3,107$ &, 002 \\
\hline
\end{tabular}

$\mathrm{df}=(\alpha / 2 ; \mathrm{n}-\mathrm{k}-1)$

$\mathrm{df}=(0,05 / 2 ; 100-3-1)$ maka

$\mathrm{Df}=(0,025 ; 96)$

Dengan melihat tabel $\mathrm{t}(0,025 ; 96)$ didapat $\mathrm{t} 1,98$ yang berarti lebih besar dari nilai $\mathrm{t}$ pada perhitungan SPSS untuk semua atribut dan berdasarkan nilai signifikansi keseluruhan kurang dari 0,025 yang berarti masing-masing atribut atau variabel berpengaruh terhadap probabilitas pemilihan moda. 


\section{Grafik Pemilihan Moda}

Grafik pemilihan moda merupakan hubungan antar probabilitas pemilihan moda dengan selisih utilitas kereta api dengan bus.

Tabel 7. Probabilitas Pemilihan Moda dengan Model Logit Binomial

\begin{tabular}{|c|c|c|c|c|c|c|c|}
\hline \multirow[b]{2}{*}{ No } & \multirow[b]{2}{*}{ Opsi } & Biaya & Waktu & Waktu & \multirow[b]{2}{*}{ U(KA-BUS) } & \multirow[b]{2}{*}{ Pr. KA } & \multirow[b]{2}{*}{ Pr. Bus } \\
\hline & & $\begin{array}{l}\text { (Ribuan } \\
\text { Rupiah) }\end{array}$ & $\begin{array}{l}\text { Tunggu } \\
\text { (menit) }\end{array}$ & $\begin{array}{l}\text { Tempuh } \\
\text { (menit) }\end{array}$ & & & \\
\hline \multirow{5}{*}{1} & A & 40 & 120 & $-2,5$ & 0,5737853 & 0,3645893 & 0,6354107 \\
\hline & B & 45 & 120 & $-2,5$ & 0,4768754 & 0,3228948 & 0,6771052 \\
\hline & c & 50 & 120 & $-2,5$ & 0,3963332 & 0,2838386 & 0,7161614 \\
\hline & D & 55 & 120 & $-2,5$ & 0,3293942 & 0,2477777 & 0,7522223 \\
\hline & $E$ & 60 & 120 & $-2,5$ & 0,2737609 & 0,2149233 & 0,7850767 \\
\hline \multirow{5}{*}{2} & A & 40 & 120 & $-2,5$ & 0,5737853 & 0,3645893 & 0,6354107 \\
\hline & B & 40 & 150 & $-2,5$ & 0,4380159 & 0,3045974 & 0,6954026 \\
\hline & c & 40 & 180 & $-2,5$ & 0,3343724 & 0,250584 & 0,749416 \\
\hline & D & 40 & 210 & $-2,5$ & 0,255253 & 0,2033479 & 0,7966521 \\
\hline & $E$ & 40 & 240 & $-2,5$ & 0,1948549 & 0,1630783 & 0,8369217 \\
\hline \multirow{5}{*}{3} & A & 40 & 120 & $-2,5$ & 0,5737853 & 0,3645893 & 0,6354107 \\
\hline & B & 40 & 120 & -2 & 0,4814273 & 0,3249753 & 0,6750247 \\
\hline & c & 40 & 120 & 1,5 & 0,1409289 & 0,1235212 & 0,8764788 \\
\hline & D & 40 & 120 & 1 & 0,1679649 & 0,1438099 & 0,8561901 \\
\hline & $E$ & 40 & 120 & 0,5 & 0,2001877 & 0,166797 & 0,833203 \\
\hline
\end{tabular}

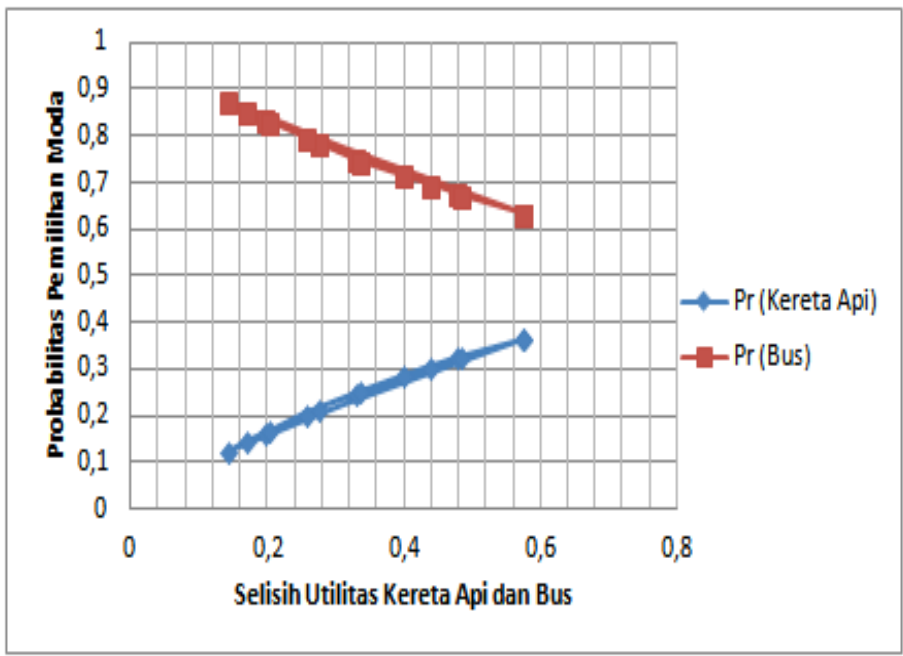

Gambar 18. Grafik Probabilitas Pemilihan Moda dengan Selisih Utilitas 


\section{Sensitivitas Model}

Sensitivitas model dimaksudkan untuk mengetahui perubahan nilai probabilitas pemilihan moda kereta api jika dilakukan perubahan nilai atribut yang diteliti.

a) Sensitivitas terhadap biaya perjalanan

Berdasarkan analisa sensitivitas terhadap perubahan atribut biaya perjalanan antara kereta api dan bus diperoleh hasil seperti grafik berikut.

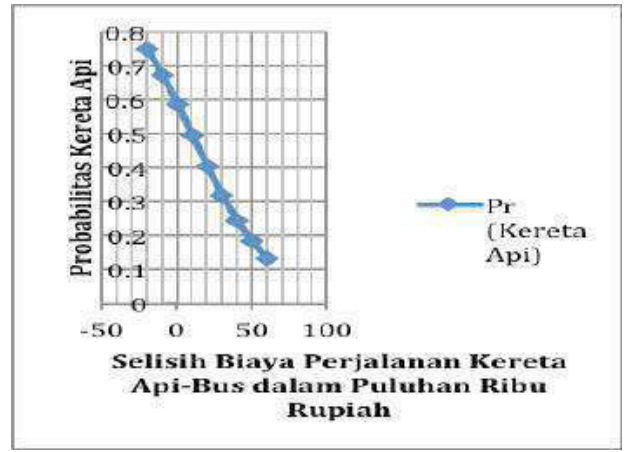

Gambar 19. Sensitivitas Model Terhadap Perubahan Biaya Perjalanan Antara Kereta Api dan bus

b) Sensitivitas terhadap perubahan waktu tunggu keberangkatan

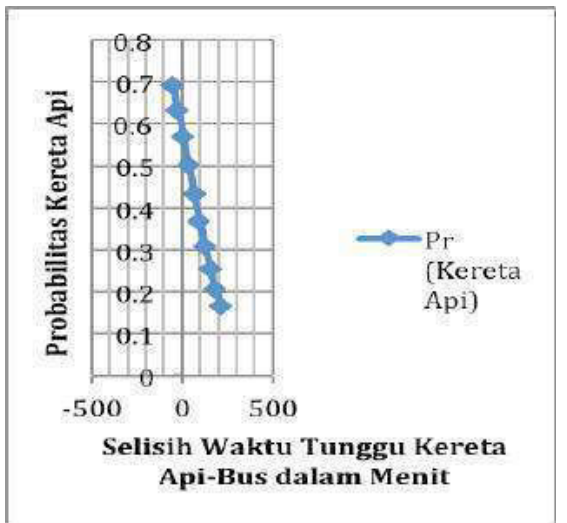

Gambar 20. Sensitivitas Model Terhadap Perubahan Waktu Tunggu Keberangkatan Antara Kereta Api dengan Bus

c) Sensitivitas teradap waktu tempuh perjalanan

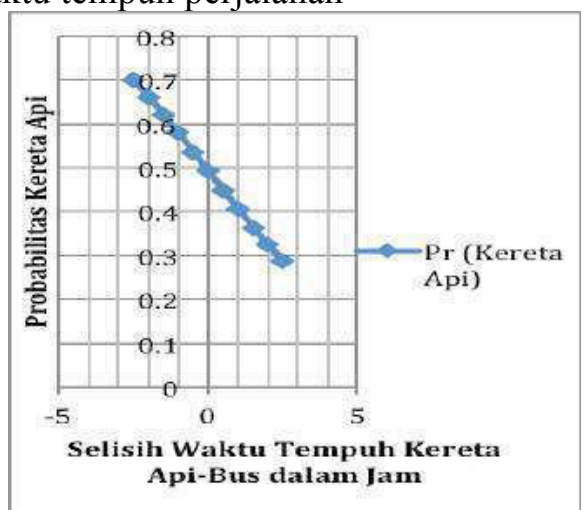

Gambar 21. Sensitivitas Model Terhadap Perubahan Waktu Tempuh Perjalanan Antara Kereta Api dengan Bus 


\section{Kesimpulan}

a Karakteristik Pelaku Perjalanan

- Pada penelitian ini mayoritas responden berjenis kelamin laki-laki, dengan persentase sebanyak $52 \%$.

- Mayoritas responden berusia antara 18-27 tahun, dengan persentase sebanyak $76 \%$ dari total keseluruhan.

- Tingkat pendidikan terbanyak responden ialah pendidikan SMA sebanyak $66 \%$.

- Sebagian besar responden masih berstatus pelajar/mahasiswa, yaitu sebanyak $46 \%$.

- Pengeluaran responden terbanyak yaitu Rp. 500.000- Rp. 1.000.000 dengan persentase sebanyak $34 \%$.

- Mayoritas responden tidak memiliki kendaraan pribadi, yaitu sebanyak $48 \%$.

b Karakteristik Perjalanan

- Mayoritas responden memilih moda yang digunakan dengan alasan pertimbangan kenyamanan, yaitu sebanyak $40 \%$ dari total keseluruhan responden.

- Maksud perjalanan mayoritas responden yaitu untuk silaturahmi/mengunjungi keluarga, dengan persentase sebesar $38 \%$.

- Mayoritas responden melakukan perjalanan dengan frekuensi waktu yang tidak tentu, yaitu sebesar $57 \%$.

- Mayoritas responden melakukan perjalanan dimulai dengan asal perjalanan dari rumah, yaitu sebanyak $51 \%$.

- Sebagian besar responden melakukan perjalanan dengan tempat tujuan perjalanan adalah rumah/perumahan, yaitu sebesar $78 \%$.

- Berdasarkan preferensi responden terhadap pengoperasian kereta api rute MedanKotapinang sebanyak 63\% responden memilih akan menggunakan kereta api.

- Berdasarkan pendapat mayoritas responden mengenai tarif yang layak untuk tiket kereta api yaitu berkisar antara Rp. 100.001 - Rp. 120.000, dengan persentase sebanyak $45 \%$.

- Mayoritas responden berpendapat bahwa tarif maksimum untuk kereta api ialah berkisar antara Rp. 100.001 - Rp. 120.000, yaitu sebanyak 38\%.

c Atribut biaya perjalanan, waktu tempuh dan waktu tunggu keberangkatan memiliki pengaruh yang cukup besar terhadap responden dalam menentukan moda yang akan digunakan dalam melakukan perjalanannya, apakah akan tetap menggunakan moda eksisting berupa bus atau beralih menggunakan kereta api. Berikut merupakan hasil dari analisa data survey stated preferenced yang telah dilakukan berupa fungsi utilitas dan model probabilitas:

- Fungsi Utilitas:

$$
\mathrm{U}_{\mathrm{KA}}-\mathrm{U}_{\mathrm{Bus}}=1,127-0, \mathrm{~L} 37 X_{2}-\mathrm{0,009} X_{2}-0,351 x_{2}
$$

- Model Probabilitas:

$$
\begin{aligned}
& P_{K A}=\frac{s^{1.127-0.037 x_{1}-0,009 X_{2}-0.351 X_{3}}}{:+c^{1,127-0,037 X_{1}-0,009 X_{2}-0,351 x_{3}}} \\
& \mathrm{P}_{\text {Bus }}=1-\mathrm{P}_{\mathrm{KA}}
\end{aligned}
$$

Model tersebut memiliki $\mathrm{R}^{2}$ sebesar 0,114 atau $11,4 \%$ yang berarti atribut yang dipertimbangkan memiliki korelasi yang lemah dan terdapat atribut-atribut lain yang berpengaruh yang belum dipertimbangan. Dan diketahui dari persamaan utilitas tersebut, atribut yang paling berpengaruh adalah atribut waktu tempuh (time). 
d Hasil analisa sensitivitas yang dilakukan memberikan hasil sebagai berikut:

Pada analisa sensitivitas perubahan atribut biaya perjalanan akan diperoleh probabilitas pemilihan kereta api lebih besar jika selisih biaya antara kereta api dan bus adalah 30 yaitu sebanyak $31,93 \%$. Sedangkan saat analisa sensitivitas terhadap perubahan atribut waktu tunggu, probabilitas pemilihan kereta api akan lebih besar jika selisih waktu tunggu lebih kecil dari 30 menit yaitu sebanyak 50,15\%. Dan pada analisa sensitivitas selisih waktu tempuh diperoleh probabilitas sebanyak 57,96\% responden akan berpindah menggunakan kereta api jika selisih waktu tempuh kereta api lebih cepat 1 jam (60 menit).

\section{Saran}

Berdasarkan hasil analisa yang telah dilakukan pada penelitian ini terdapat saran dari penulis: Jika dilihat dari sensitivitas selisih atribut biaya perjalanan menggunakan kereta api maka penulis menyarankan kepada pihak yang berwenang dalam pengoperasian serta penentu kebijakan tarif kereta api agar biaya perjalanan menggunakan kereta api sama dengan biaya perjalanan dari Medan menuju Rantau Prapat yaitu sebesar Rp. 110.000 untuk memperbesar probabilitas penumpang yang menggunakan moda bus agar berpindah menggunakan moda kereta api.

\section{Daftar Pustaka}

Djoeddawi, A.H.N. (2015). Model Pemilihan Moda Antara Kereta Api dan Bus Rute MakassarParepare dengan Menggunakan Metode Stated Preference. Jurnal Universitas Brawijaya. Malang.

Ginting, R. (2015). Kuesioner Alat Ukur Kepuasan Konsumen Terhadap Produk. Medan: USU Press.

Israel, G.D. (2012). Determining Sample Size. University of Florida

Miro, F. (2005). Perencanaan Transportasi untuk Mahasiswa, Perencana, dan Praktisi. Jakarta: Penerbit Erlangga.

Miro, F. (2016). Analisis Pilihan Moda Transportasi Umum Rute Padang-Jakarta Menggunakan Metode Stated Preference. Journal of Regional and City Planning. 27(1). 25-33.

Muhammad, R. (2015). Analisa Pemilihan Moda Transportasi Antara Shuttle Service dengan Kereta Api dengan Menggunakan Metode Stated Preference (Studi Kasus: Bandung-Jakarta). Universitas Sumatera Utara.

Nurdiansyah, M.F. (2015). Analisis Probabilitas Perpindahan Moda dari Bus ke Kereta Api Siliwangi Jurusan Sukabumi-Cianjur Menggunakan Analisis Regresi Logit Biner. Jurnal Teknik ITS. 4(1).

Oktaviani, A.Y.S. (2015). Alternatif Pemilihan Moda Transportasi Umum (Studi Kasus: Bus dan Kereta Api Trayek Kota Padang-Kota Pariaman. Annual Civil Engineering Seminar.

Sihite, S. (2015). Kajian Pemilihan Moda Transportasi Antara Angkutan Kota dengan Monorel Menggunakan Metode Stated Preference (Studi Kasus: Rencana Pembangunan Monorel Kota Medan. Tugas Akhir Universitas Sumatera Utara.

Simanjuntak, E. F. Analisis Pemilihan Moda Transportasi Bus Angkutan Kota dan Kereta Api Rute Medan Tanjung Balai Terhadap Kenaikan Harga BBM. Tugas Akhir Universitas Sumatera Utara.

Tamin, O.Z. (2008). Perencanaan, Pemodelan, dan Rekayasa Transportasi. Bandung: Penerbit ITB. 